\title{
Dialysis encephalopathy, bone disease and anaemia: the aluminium intoxication syndrome during regular haemodialysis
}

\author{
IS PARKINSON, MK WARD, DNS KERR \\ From the Department of Medicine, University of Newcastle upon Tyne
}

\section{DIALYSIS ENCEPHALOPATHY}

\section{Clinical features}

Dialysis encephalopathy, now attributed to aluminium intoxication, is a complication of prolonged haemodialysis first described in $1972 .{ }^{1}$ Initially the condition was over-diagnosed, and at meetings of the European Dialysis and Transplant Association and the American Society of Nephrology almost half the audience claimed to have seen at least one case. In the light of subsequent studies it seems likely that many of these claims were based upon the misinterpretation of other neurological syndromes in renal failure.

However to one who has lived through an "epidemic" of this disease, the clinical picture is readily distinguished from that of most other neurological disorders. Usually the first symptom is a characteristic alteration in speech; this is partly a dysarthria due to disordered muscle action and, at the height of an attack, the tongue can be miraculously loosed by an injection of diazepam. ${ }^{2}$ However as the disease progresses dysphasia coexists with dysarthria. Speech disturbance is initially intermittent, often precipitated by dialysis, but becomes continuous. Other early features are myoclonic jerks and grand mal seizures. Two characteristic features are dyspraxia, which affects the handwriting at an early stage, and rapid fatiguability which causes performance of all structural tasks to deteriorate within a few minutes of sustained effort. Global dementia supervenes but insight is often retained until late in the illness; this is a distressing feature since the patient has often seen his fellow patients die of the same condition and appears to know what is happening to him. In the terminal stages facial grimacing, myotonic spasms and dysphagia interfere with eating and lead to inhalation pneumonia. Death occurs from inanition, infection or deliberate withdrawal of treatment.

Some of the data quoted are taken from a PhD thesis by ISP.
The major symptoms of 21 patients seen in Newcastle are shown in Table 1. Fuller descriptions of the symptomatology are contained in several recent reviews. ${ }^{3-7}$

Table 1 Dialysis encephalopathy syndrome in 21 cases

\begin{tabular}{lr}
\hline Dysarthria/dysphasia & 21 \\
Dementia & 21 \\
Myoclonus & 16 \\
Seizures & 8 \\
Ataxia & 8 \\
\hline
\end{tabular}

Lumbar puncture has been uninformative; nearly all authors have reported normal CSF pressure, cell count and concentrations of protein, glucose and chloride. The brain atrophy to be expected in a dementing disease has been inconspicuous in the few reported studies; air encephalograms were normal in two patients ${ }^{8}{ }^{9}$ and so were computerised axial tomographic (CAT) scans in 14 others. ${ }^{10} 11$ However the Chicago group found slight dilatation of the ventricles on CAT scanning in one patient and abnormal CSF dynamics, revealed by cysternography with radioiodinated human serum albumin, in seven others. ${ }^{12}$ Isotopic brain scans have been consistently normal. ${ }^{8-12}$

The one laboratory test that has proved extremely useful is the electroencephalogram (EEG). A characteristic pattern of spikes and slow waves appears early in the course of the disease. ${ }^{1-313}$

After successful renal transplantation patients with early disease gradually recover (Table 2). ${ }^{1415}$ Over the course of one or two years speech deficit diminishes but seldom disappears completely. Patients who have regained normal speech under the quiet conditions of home life become dysphasic again when embarrassed-for example, by being shown in front of a large medical audience. When patients are transplanted late in the course of the disease the downhill progress is not arrested. It is therefore crucially important to diagnose the disease at an early, reversible stage. This is difficult even when 285 
Table 2 Result of attempts to reverse encephalopathy at Newcastle

\begin{tabular}{lr}
\hline Cadaver transplantation & \\
Graft successful: & 5 \\
$\quad$ Early neurological disease stabilised & 1 \\
$\quad$ Early disease progressed & 2 \\
$\quad$ Late disease progressed & 3 \\
Graft failed; patient returned to dialysis with high aluminium & \\
$\quad$ dialysate: dementia progressed & 1 \\
Transferred to purer dialysate & 3 \\
Moved to Sunderland & Dialysate made from distilled or deionised water: disease \\
$\quad$ stabilised & 3 \\
Total & 15 \\
\hline
\end{tabular}

*Aluminium concentration in Sunderland tap water $<30 \mu \mathrm{g} / \mathrm{l}$.

suspicions are heightened by a continuing epidemic.

The early features probably include a reduced performance IQ and abnormal responses to other tests of higher functions such as calculating ability. Two studies have shown progressive impairment of such tests with length of exposure to dialysis; one was in Newcastle, at a time when aluminium exposure was unchecked and cases of encephalopathy were still appearing; ${ }^{16}$ the other was in a centre where aluminium exposure was apparently suspected since plasma aluminium was included in the investigations, but no results for serum aluminium were reported and no information was given on the local incidence of encephalopathy. ${ }^{17}$ A speech-screening assessment, carried out by a speech therapist, has successfully detected patients with high aluminium exposure and predicted progression to overt encephalopathy. ${ }^{18}$ However early diagnosis usually depends on the alertness of the clinician to subtle changes in patient behaviour and free use of the EEG in suspected cases.

\section{Pathology}

Compared with the devastating clinical features, the pathological findings have been slight and have varied in different accounts. The topic was recently reviewed by Cartier. ${ }^{19}$ Cerebral atrophy has been slight or absent. Non-specific gliosis, accumulation of lipofuchsin or focal oedema have been described in most series ${ }^{1-1120}$ but in some the majority of patients have been described as microscopically normal. ${ }^{11} 12$ Prominent corpora amylacea were described in a few patients ${ }^{20}$ along with a few other minor and inconsistent abnormalities. The lacunae described in three patients in one study ${ }^{9}$ may well have been the result of hypertension.

Another inconstant feature reported from Denver, seen in only two patients, was loss of Purkinje cells from the cerebellum. ${ }^{20}$ This, however, was a more constant and impressive feature in Newcastle patients; $; 1$ some had virtually complete loss of Purkinje cells. Two brains studied at Rennes by a combination of electron microprobe analysis and electron microscopy revealed numerous lysosomes in brain neurones; these contained very numerous fine microcrystals identified as aluminium phosphate. ${ }^{22}$

Surprisingly little space has been devoted to neuropathology in the publications on dialysis encephalopathy. It seems unlikely that the last word has been spoken on this topic.

\section{Role of aluminium}

Initially the cause was sought in the known features of chronic renal failure, but with negative results. Half-way through the Newcastle epidemic 14 encephalopathic patients were compared with 32 other patients on regular haemodialysis. There was no significant difference in the control of uraemia, as judged by predialysis plasma creatinine (encephalopathy 1190 , range $670-1272 v$ control 1102 , range $781-1418 \mu \mathrm{mol} / \mathrm{l})$ or mean blood pressure $(130 / 76 v$ 139/84 respectively). Histopathological studies showed no evidence of other neurological disease and the younger encephalopathic patients were often remarkably free from cerebral atheroma at necropsy. Culture of the brains for slow viruses yielded negative results with one exception. For a brief period phosphate depletion was considered to be a possible causative or aggravating factor since phosphat $\mathcal{E}$ repletion produced a temporary improvement. ${ }^{23} \mathrm{How}$ ever the patients soon resumed their inexorable downe hill course despite continued phosphate treatment.

Alan Alfrey, who first described the disease, was convinced from the start that it was an intoxication. He embarked on a long search for trace-element accumulation in dialysis patients at Denver and turned up a few false clues such as modest accumulation of tin or deficiency of rubidium. ${ }^{24}$ In 1976 he reported a much more striking abnormality-a substantially increased concentration of aluminium in several tissues of patients dying of encephalopathy $;^{25}$ the concentration in brain grey matter was ten times as high as in control uraemic subjects, and in muscle and bone it was up to 100 times as high. The results were soon confirmed in Eindhoven ${ }^{26}$ and, for the brain, in Newcastle (Table 3). ${ }^{27}$

In Europe the evidence that aluminium was the

Table 3 Brain aluminium concentrations in Newcastle patients $^{27}$

\begin{tabular}{lcll}
\hline Cause of death & $\begin{array}{l}\text { No of } \\
\text { patients }\end{array}$ & $\begin{array}{l}\text { Aluminium concentrations } \\
(\mu g / g \text { dry weight })\end{array}$ \\
\cline { 2 - 4 } & & Grey matter White matter \\
\hline Encephalopathy & 7 & $20.4(31)$ & $6.9(21)$ \\
Other complications of & 12 & $5 \cdot 1(62)$ & $3.5(50)$ \\
regular haemodialysis & 12 & $2.9(11)$ & $2.7(7)$ \\
Uraemia (not dialysed) & 2 & & \\
\hline
\end{tabular}

Figures in parentheses indicate the number of tissue samples analysed. 
cause of dialysis encephalopathy was accepted almost at once. This rapid conversion of nephrologists owed a great deal to the dramatic account by Flendrig and his colleagues ${ }^{26}$ of the outbreak at Eindhoven. Two dialysis centres in the same city shared a common water supply, low in aluminium, but one of these centres was the seat of an outbreak of fatal encephalopathy which affected six patients. The source of the aluminium was traced to two aluminium anodes which were part of a cathodic protection system against corrosion in the boilers. When these anodes had been removed and the unit had moved to a new hospital a few months later, the outbreak ceased. In the United States there has been greater reluctance to accept the evidence, partly because of the authoritative opposition of Dr Allen Arieff. ${ }^{28}$ The alternative theories of causation have been fully reviewed by Bone $^{10}$ but in the authors' view they are of historic interest only. However, for the sake of American sceptics the evidence for and against aluminium as the cause will be summarised.

The evidence for tissue accumulation of aluminium has been set out above. However, two other investigations have not confirmed it. Platts and Hislop ${ }^{29}$ found only a modest increase and Pascoe and Gregory ${ }^{30}$ found none, but these were small studies and the latter has only appeared in abstract. Arieff ${ }^{28}$ found brain aluminium concentrations in demented patients fifteen times higher than normal but rejected this as evidence of cause and effect since he also found high concentrations of aluminium in the brains of patients dying of hepatic coma, metastatic cancer and uraemia without encephalopathy. Berkseth and Shapiro ${ }^{31}$ found high aluminium concentrations $(20.0,17 \cdot 6,17 \cdot 6,15.6 \mathrm{mg} / \mathrm{kg})$ in the brains of four patients who died after 32-36 months' exposure to high-aluminium dialysate, only onc of whom had encephalopathy, and lower concentrations $(8 \cdot 6,8 \cdot 6)$ in two patients who died after nine months treatment on pure dialysate following four and 36 months respectively on high-aluminium dialysate, of whom one was encephalopathic. They did not feel that this evidence supported aluminium deposition in the brain as the pathogenesis of the brain lesion, though they adduced considerable epidemiological evidence for aluminium as the cause of the disease.

However, in support of Alfrey's hypothesis, a study from Rennes showed substantially higher grey matter aluminium in dialysed patients with encephalopathy than in those without encephalopathy, ${ }^{32}$ and further work at Denver substantiated the early results, showing almost no overlap between the encephalopathic and unaffected dialysis patients. ${ }^{33}$ Although the conflict of evidence is disturbing, it must be stressed that measuring brain aluminium is difficult; the most stringent precautions are necessary to exclude contamination and no publication is interpretable without full technical details. We remain prepared to pin our faith on the careful studies at Denver, Eindhoven and Rennes along with our own from Newcastle. Fortunately for our patients, if not for our scientific curiosity, the opportunity for repeating these studies is vanishing and the issue may remain unresolved.

Consequently the evidence that is likely to convince the sceptical in the long run is epidemiological. Many outbreaks have been described in association with the use of dialysis fluid with a high concentration of aluminium, usually greater than 200 $\mu \mathrm{g} / 1.1013262732-42$ An epidemiological study of the dialysis centres in the United Kingdom showed that encephalopathy was almost unknown in those with an aluminium concentration of less than $50 \mu \mathrm{g} / \mathrm{l}$ in water used to make dialysis fluid, while its incidence rose progressively with higher water concentrations (Fig. 1). ${ }^{43}$ A similar study in France led to the

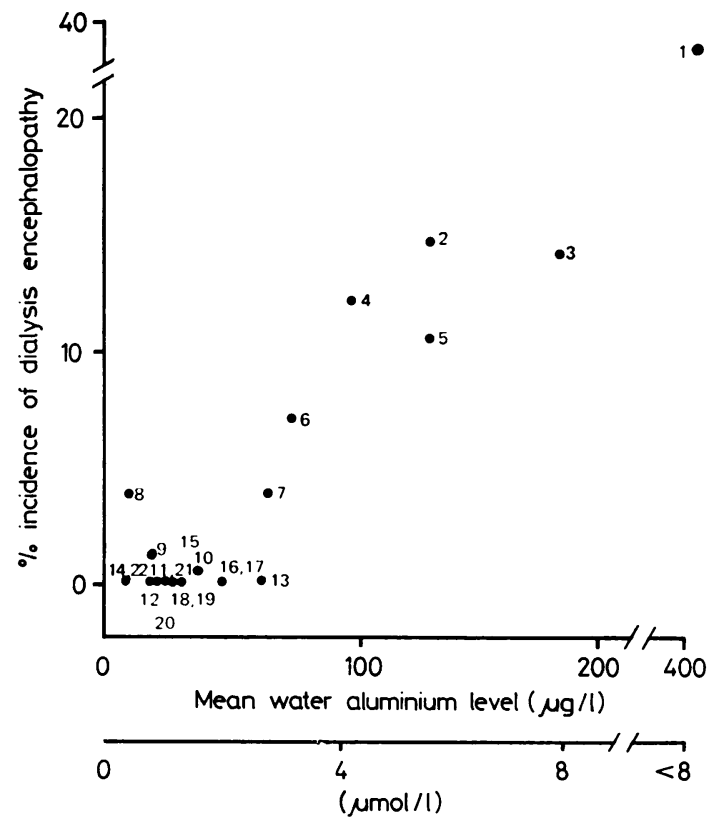

Rank correlation $=0.69$ with 20 degrees of freedom $p=0.0004$

Fishers Exact Test : cut off points

$\mathrm{Al}>50 \mathrm{\mu g} / \mathrm{l}$ encephalopathy $>5 \%$

$A l \leqslant 50 \mu g / l$ encephalopathy $\leqslant 5 \%$ $p=0.0004$

Fig. 1 Correlation of encephalopathy with mean aluminium content of the water used to make dialysis fluid in British dialysis centres. The numbers refer to the identity of the centres..$^{43}$ Reproduced by permission of the Editor of The Lancet. 


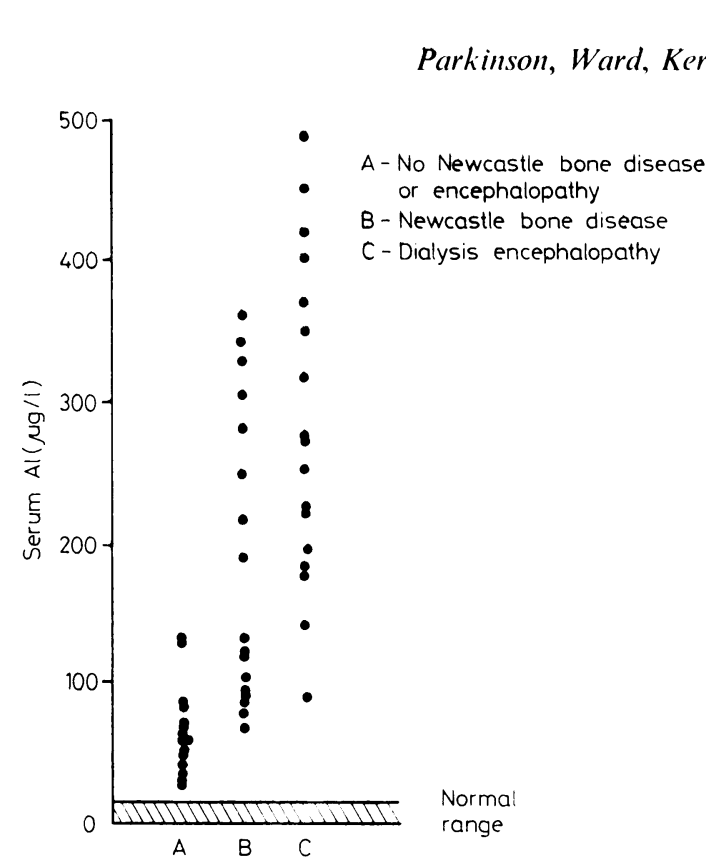

Fig. 2 Serum aluminium ( $A l)$ in haemodialysis patients, showing high aluminium levels in bone disease and encephalopathy (for methods see reference 33). Pierides, personal communication 1981). In Newcastle only one new case of encephalopathy has appeared since the introduction of purified water; this patient's home water treatment system was not removing aluminium adequately. One other patient, heavily exposed to aluminium before reverse osmosis was installed, suffered some progression of his encephalopathy afterwards, in keeping with experience after transplantation in such patients. The all but universal success of precautions against aluminium exposure in eliminating this disease is the strongest argument supporting aluminium overload as the sole cause. However it has to be acknowledged that water treatment removes many other potentially toxic substances. Of these, only manganese has some small claim to an epidemiological association with the disease ${ }^{34}$ and has been found in excess in the brains of affected patients, ${ }^{32}$ though in the white matter rather than in the histologically involved grey matter.

Some supporting evidence for the role of aluminium comes from the association between encephalopathy and high concentrations of aluminium in tissues other than brain, notably bone (discussed below) and serum or plasma (Fig. 2). The considerable overlap in most studies between the plasma aluminium concentrations of patients with encephalopathy, and those treated at the same centre who have not yet developed the disease, ${ }^{4046-48}$ is not surprising; plasma aluminium, which reflects recent exposure to a source of aluminium overload, usually the dialysate (Fig. 3), takes a few weeks to change when water purification is introduced. ${ }^{41}$ Cerebro-

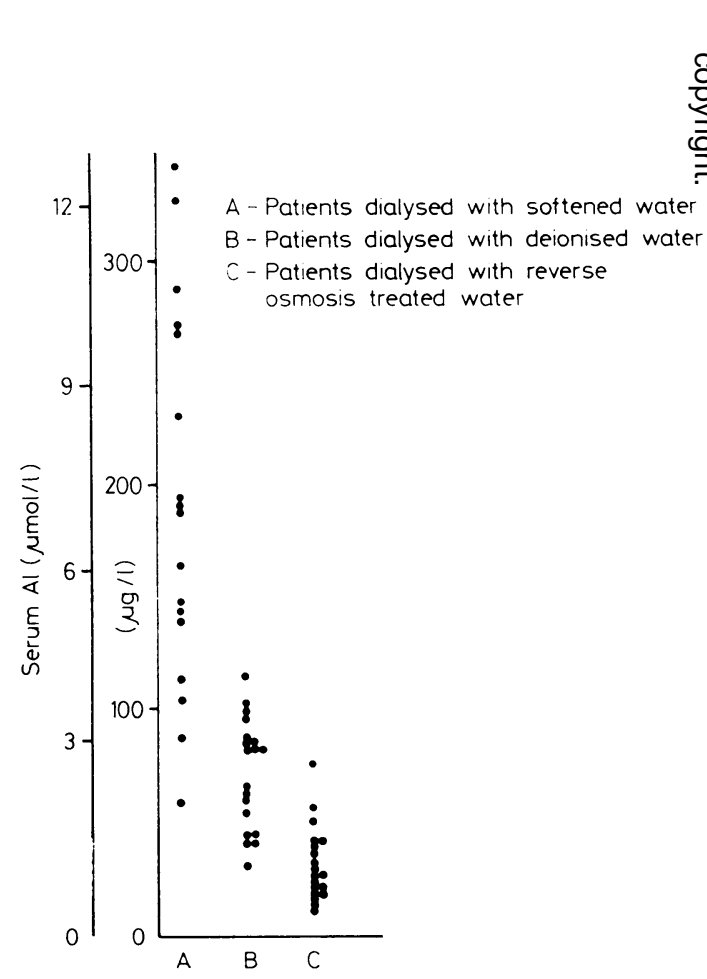

Fig. 3 Serum aluminium $(A l)$ in patients on regular haemodialysis on different forms of water treatment. Measurements were made immediately before dialysis. 


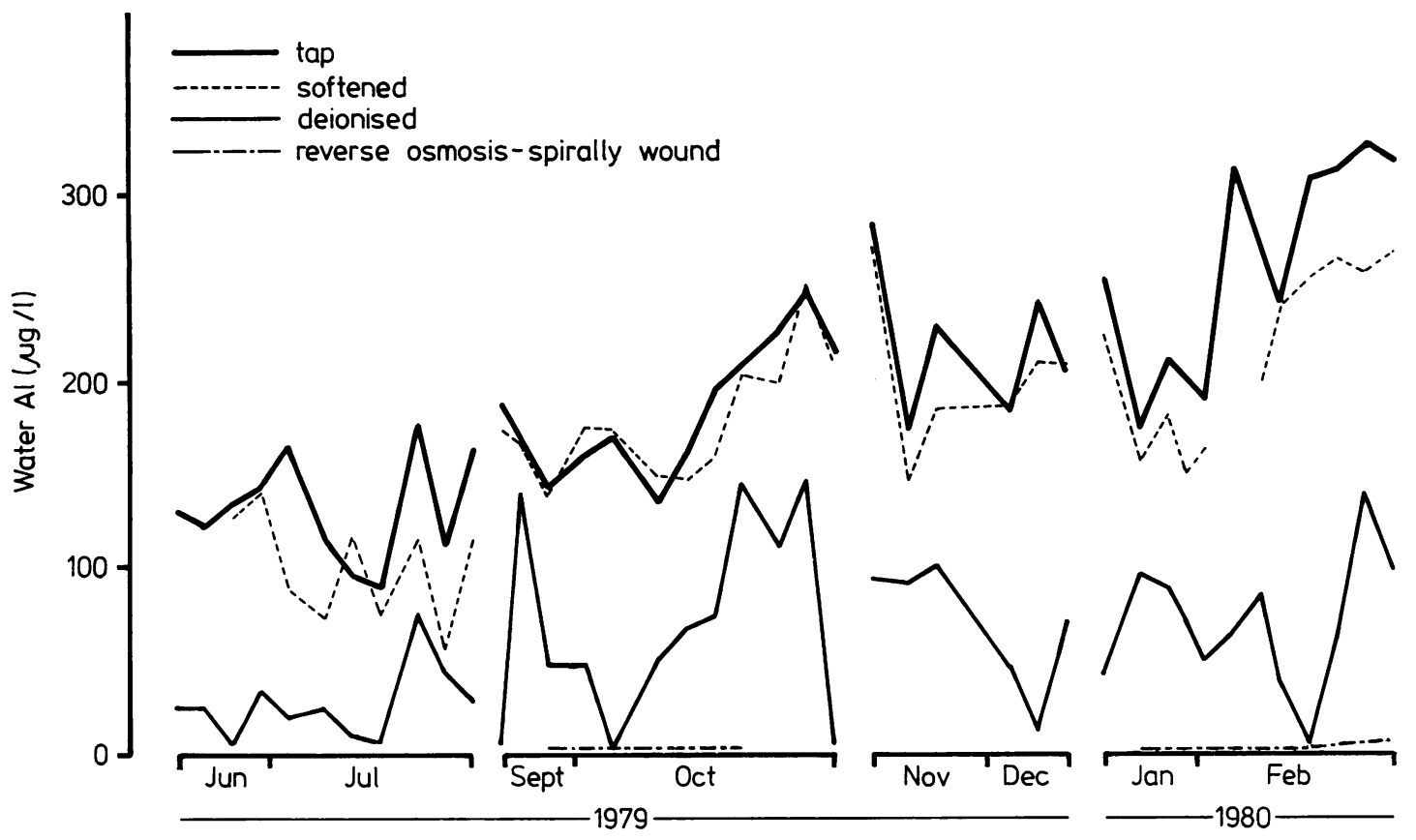

Fig. 4 Effects of softening, deionisation and reverse osmosis on aluminium $(A l)$ content of Newcastle tap water.

spinal fluid aluminium has received little attention but appears to have a closer association than plasma aluminium with the presence of encephalopathy. ${ }^{48}$ The total body burden of aluminium cannot be measured easily, but can be estimated from whole body neutron activation; it is raised by several grams in patients with encephalopathy. ${ }^{49}$

\section{Dialysate aluminium}

With one exception, all published outbreaks of encephalopathy have been traced to aluminium contamination of the dialysis fluid. The unusual source of aluminium at Eindhoven ${ }^{26}$ has been described above; the commoner source is treatment of surface water by the water authority to remove organic materials affecting its colour and taste. The first stage of this process is flocculation. Aluminium sulphate is a popular flocculating agent since the residue of alum which remains after the process does not affect either the colour or the taste of water. This residual aluminium content varies from day to day (Fig. 4) reflecting weather conditions which affect the organic content of the water. The chemical formulation of residual aluminium also varies; it changes from aluminium salts through colloidal particles to aluminates as the $\mathrm{pH}$ rises. The solubility curve is therefore U-shaped (Fig. 5). Although the

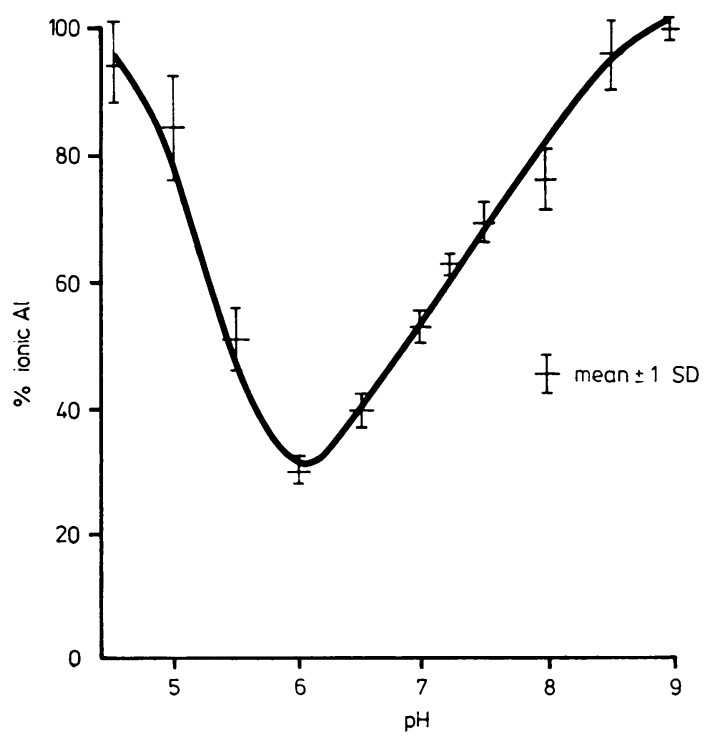

Fig. 5 Effect of $\mathrm{pH}$ on the proportion of ionised aluminium (Al) in Newcastle tap water (4 samples). 
resins of water softeners have a high affinity for aluminium they do not remove it reliably from water supplies (Fig. 4). ${ }^{21} 3436424850-52$ Deionisers are much more effective and have often been sufficient to halt an outbreak. In Sheffield they have even permitted improvement of affected patients. ${ }^{34} 35$ However they are not totally reliable in all water supplies (Fig. 4). Twin bed deionisers seem likely to be more effective than mixed bed dzionisers. Reverse osmosis has been consistently effective in Newcastle (Fig. 4) but there have been occasional exceptions elsewhere. ${ }^{53}$ The best arrangement is a water softener, reverse osmosis and deioniser in series; the cost is fully justified in areas with high tap water aluminium. ${ }^{41}$ Whatever system is chosen, it should be tested on the local water supply and monitored regularly.

When dialysate $\mathrm{pH}$ is carefully controlled at close to 7.0 much of the aluminium is in colloidal form, and at this $\mathrm{pH}$, dialyser clearance was found to be low, ${ }^{54}$ at least in vitro. The importance of dialysis fluid $\mathrm{pH}$ is emphasised by the Redy system of dialysate regeneration* which releases more aluminium from the cartridge when used with bicarbonatecontaining dialysis fluid than with the usual acetate solution. ${ }^{55}$ However, most studies of dialyser alumin*See page 1283 (Rosemarie Baillod)
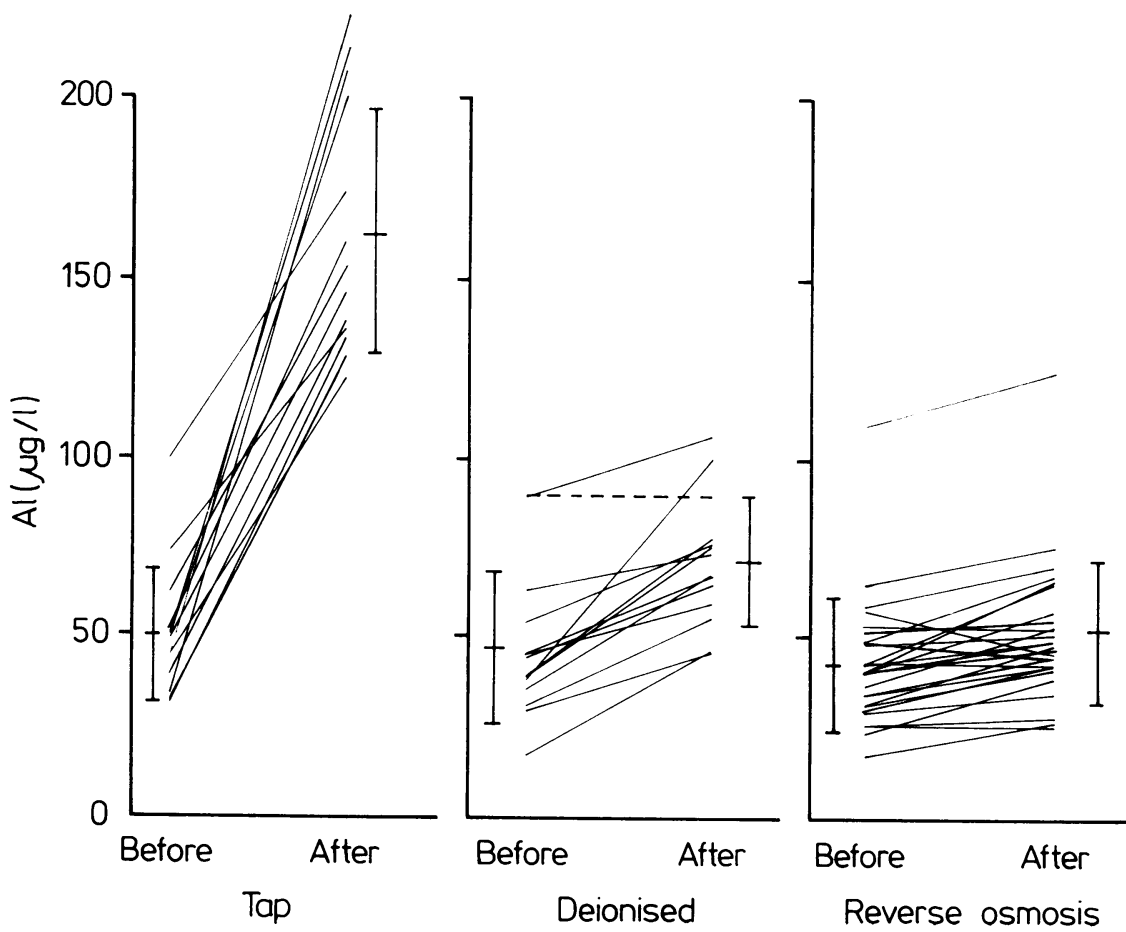

Fig. 6 Change in serum aluminium $(A l)$ during a single haemodialysis in Newcastle patients whose dialysis fluid was made from water that was (a) untreated, (b) deionised, (c) treated by reverse osmosis. 
overload in dialysis encephalopathy ${ }^{25}$ and soon showed by sensitive techniques that even normal subjects had a rise of serum aluminium within a few days while ingesting aluminium hydroxide. ${ }^{63}$ This has been confirmed for patients in chronic renal failure who were not on dialysis ${ }^{64-66}$ or were dialysed against very low concentrations of aluminium. ${ }^{67}$ In general the serum concentrations attained in these studies have been well below those found in patients with encephalopathy (Fig. 7). A survey conducted by

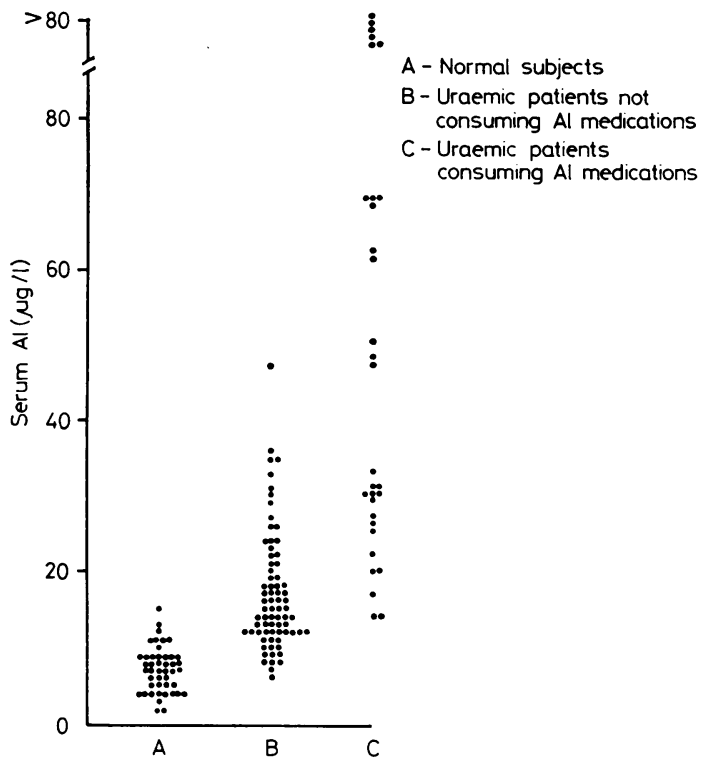

Fig. 7 Serum aluminium $(A l)$ in normal subjects and subjects with chronic renal failure not treated by dialysis.

the Registry of the European Dialysis and Transplant Association found no correlation between oral intake of aluminium hydroxide and incidence of dialysis encephalopathy. ${ }^{68}$ Tens of thousands of patients have taken aluminium hydroxide to control plasma phosphate in chronic renal failure without developing encephalopathy. Consequently it has now been generally assumed that the risk of dangerous aluminium overload from this source is small or negligible.

However there are a few disturbing facts that leave a question mark over the safety of oral aluminium in renal failure. One large outbreak of encephalopathy involved 13 patients who were dialysed against very low concentrations of aluminium. ${ }^{11}$ This event was so unusual that some other source of aluminium overload, not yet revealed by the careful investigations at Nashville, must be suspected. Several other isolated cases or small outbreaks have been attributed to aluminium ingestion but must be accepted with some reserve since the patients were dialysed against fluid which contained $50-80 \mu \mathrm{g} / 1$ of aluminium ${ }^{39} 69$ or was of unstated aluminium content. ${ }^{70}$ Even if these cases are discounted as unproven, there remains a hard core of published cases which are difficult to dismiss. At least four patients have developed "dialysis encephalopathy" without ever being dialysed. 7172 In another patient, a rise in serum aluminium and the appearance of symptoms coincided with oral aluminium administration on two occasions. ${ }^{73}$ In one outbreak encephalopathy stopped occurring, and affected patients improved, when oral administration of aluminium was discontinued, without any reported change in dialysis conditions. ${ }^{70}$ A few patients in Newcastle have developed very high plasma aluminium concentrations after prolonged administration of aluminium hydroxide for stable chronic renal failure. Different preparations of aluminium hydroxide and other compounds differ in their ability to bind phosphate ${ }^{74}$ or release aluminium. ${ }^{63}$ It is concluded that oral administration of aluminium hydroxide is a rare cause of serious aluminium overload and that patients in renal failure receiving large doses over long periods should have regular checks of serum aluminium.

\section{Treatment}

This disease is easier to prevent than to treat. The beneficial effects of transplantation at an early stage have been mentioned above. Impressive reversal of early disease has been achieved also by rigorous exclusion of aluminium from the dialysis fluid and oral medications. ${ }^{41}$ However there was little to offer the patient with well developed disease until the introduction of chelation therapy by Ackrill and his colleagues. ${ }^{75}$ The effectiveness of desferrioxamine in removing tissue aluminium has been confirmed indirectly by others ${ }^{59}$ but there are no published data so far on direct tissue measurement, and only preliminary information on changes in cerebral function. The striking improvement in handwriting and other tests of constructional ability in patients with moderately severe disease treated by removal of the source of aluminium ${ }^{45}$ gives ground for some optimism.

\section{ASSOCIATED FEATURES}

\section{Bone disease}

Osteomalacia, diagnosed histologically, affects about $20 \%$ of patients in terminal renal failure. ${ }^{76}$ In general, treatment with regular haemodialysis and vitamin $D$ analogues heals or improves most of these patients but it has become apparent in the last 13 years that some dialysis centres were characterised 
by progressive development of a severe form of osteomalacia causing bone pain, fractures, severe deformity and myopathy, in which serum alkaline phosphatase was usually normal or low, serum calcium was sometimes high and readily raised by administration of calcium or vitamin $\mathrm{D}$, and the bone lesion was unresponsive to vitamin $\mathrm{D}$ or its newer analogues. In Europe the disease has become known as "Newcastle bone disease" because of its high incidence in Northern England and our interest in the topic. Fuller descriptions of the syndrome, and the evidence that it is caused by aluminium in bone, have been presented elsewhere. ${ }^{43}$ 76-78 Two recent advances in understanding have been the reproduction of the disease in rats by aluminium administration $^{79}$ and the application of histochemical stains for aluminium, which have been verified by other techniques and which have shown aluminium localised in the mineralising layer of the osteoid. ${ }^{80}$ It is now possible to recognise the disease with some confidence from a simple undecalcified bone biopsy without the considerable effort required to measure bone aluminium by neutron activation.

Papers continue to appear from the United States describing this form of bone disease and containing statements like "the cause of this severe osteomalacia, which occurs despite normal or slightly elevated levels of serum calcium and fails to mineralize with calcitriol, is unclear." $"$ It is suggested that the evidence presented or reviewed in the articles quoted above makes it extremely likely that "this severe osteomalacia" is another manifestation of aluminium overload.

\section{Anaemia}

Patients with dialysis encephalopathy are generally sick. They often lose weight and look ill. It is likely that several tissues other than brain and bone are affected. A microcytic anaemia is associated with dialysis encephalopathy ${ }^{4151}$ and remits when exposure to aluminium is reduced. ${ }^{82}$ It may prove to be a useful early warning of the syndrome since in an Edinburgh series it preceded clinical evidence of bone disease and encephalopathy in many of the patients. ${ }^{82}$

\section{References}

1 Alfrey AC, Mishell JM, Burks J, et al. Syndrome of dyspraxia and multifocal seizures associated with chronic hemodialysis. Trans Am Soc Artif Intern Organs 1972; 18:257-61.

${ }^{2}$ Nadel AM, Wilson WP. Dialysis encephalopathy: a possible seizure disorder. Neurology $(N Y)$ 1976;26:11304.

${ }^{8}$ Mahurkar SD, Dhar SK, Salta R, Meyers L, Smith EC, Dunea G. Dialysis dementia. Lancet 1973 ; i:1412-5.

${ }^{4}$ Kerr DNS. Clinical and pathophysiologic changes in patients on chronic dialysis: the central nervous system. In: Maxwell MH, ed. Advances in nephrology. Vol 9. Medical Year Book Publishers, 1980:109-32.

"Chui HC. Damasio AR. Progressive dialysis encephalopathy ("Dialysis dementia"). J Neurol 1980;222:145-57.

${ }^{6}$ A rieff AI. Neurological complications of uremia. In: Brenner BM. Rector FC, eds. The kidne'. Philadelphia: Saunders, $1981: 2306-43$.

' Kerr DNS, Ward MK, Parkinson IS. Dialysis encephalopathy: questions and answers. In: Cummings NB, ed. Proceedings of the Chronic Renal Disease Conference. NIH, 1980. Department of Health, Fducation and Welfare, 1981.

* Barratt LJ. Lawrence JR. Dialysis-associated dementia. Aust NZJ Med 1975;5:62-5.

"Chokroverty S, Bruetman ME, Berger V. Reyes MG. Progressive dialytic encephalopathy. J Neurol Neurosurg Psychiatry 1976;39:411-9.

1" Bone I. Progressive dialysis encephalopathy. In: Davison AM, ed. Dialysis revien. Tunbridge Wells: Pitman. 1978:216-29.

"Dewberry FL. McKinney TD, Stone WJ. The dialysis dementia syndrome: report of fourteen cases and review of the literature. ASAIO J 1980;3:102-8.

12 Mahurkar SD. Smith EC, Mamdani BH. Dunea (;. Dialysis dementia - the Chicago experience. J Dial 1978: 2:447-58.

${ }^{13}$ Ma'jurkar SD, Meyers L. Cohen J, Kamath RV, Dunea (i. Electroencephalogranhic and radionuclide studies in dialysis dementia. Kidney Int 1978;13:306-15.

"Silke B. Fitzgerald GR. Hanson S. Carmody M. O`Dwyer WF. Dialysis dementia and renal transplantation. Dial Transplant 1978;7:486-7.

15 Sullivan PA. Murnaghan DJ, Callaghan N. Dialys dementia: recovery after transplantation. $B r M c d J 197$ Z ii: 740 .

${ }^{16}$ English A, Savage RD. Britton PG, Ward MK. Ke DNS. Intellectual impairment in chronic renal failure? Br Med J 1978;i:888-90.

1: Gilli P, Bastiani P. Rosati G, e't al. Impairment of the mental status of patients on regular dialysis treatment. Pro: Eur Dial Transplant Assoc 1980:17:306-11.

is Ackrill P, Barron J, Whiteley S. Horn AC, Ralston AJ. A new approach $t$ c the early detection of dialysis encephalopathy. Pris Eur Dial Transplant Assuc 1979:16:65960.

19 Cartier F, Chatel M, Allain P. Aluminium toxicity in renal failure. In: Zurukzoglu W, Papadimitriou M, Pyrpasopoulos M, Sion M, Zamboulis C, eds. Proceedings of the Eighth International Congress of Nephrology. Basle: Karger, 1981:1922-9.

20 Burks JS, Alfrey AC, Huddlestone J, Norenberg MD, Lewin E. A fatal encephalopathy in chronic haemodialysis patients. Lancet 1976; i:764-8.

21 Ward MK. Pierides AM, Fawcett P, et al. Dialysis encephalopathy syndrome. Proc Eur Dial Transplant Assoc 1976;13:348-54.

${ }^{22}$ Galle P, Chatel M, Berry JP, Menault F. Encéphalopathie myoclonique progressive des dialysés: présence d'aluminium en forte concentration dans les lysosomes des $\sigma$ cellules cérébrales. Nouve Presse Med 1979;8:4091-4.

${ }^{23}$ Pierides AM, Ward MK, Kerr DNS. Haemodialysis encephalopathy: possible role of phosphate depletion. Lancet $1976 ; \mathrm{i}: 1234-5$.

24 Rudolph H, Alfrey AC, Smythe WR. Muscle and serum trace element profile in uremia. Trans Am Soc Artif Intern Organs 1973;19:456-61.

${ }^{25}$ Alfrey AC, LeGendre GR, Kaehny WD. The dialysis $\stackrel{?}{+}$ encephalopathy syndrome. Possible aluminum intoxication. $N$ Engl J Med 1976;294:184-8. 
${ }^{26}$ Flendrig JA, Kruis H, Das HA. Aluminium intoxication: the cause of dialysis dementia? Proc Eur Dial Transplant Assoc 1976;13:355-61.

27 McDermott JR, Smith Al, Ward MK, Parkinson IS, Kerr DNS. Brain-aluminium concentration in dialysis encephalopathy. Lancet 1978; :901-4.

${ }^{28}$ Arieff AI, Cooper JD, Armstrong D, Lazarowitz VC. Dementia, renal failure and brain aluminum. Ann Intern Med 1979;90:741-7.

29 Platts MM, Hislop JS. Aluminium and dialysis encephalopathy. Lancet 1976 ;ii:98.

${ }^{30}$ Pascoe MD, Gregory MC. Dialysis encephalopathy: aluminum concentration in dialysate and brain. Kidney Int 1979;16:90.

${ }^{31}$ Berkseth RO, Shapiro FL. An epidemic of dialysis encephalopathy and exposure to inigh aluminum dialysate. In: Schreiner GE, Winchester JF, Mendelson BF, eds. Controversies in nephrology vol 2. Washington: Georgetown University, 1980:42-51.

${ }^{32}$ Cartier F, Allain P, Gary J, Chatel M, Menault F, Pecker $S$. Encéphalopathie myoclonique progressive des dialysés. Rôle de l'eau utilisée pour l'hémodialyse. Nouve Presse Med 1978;7:97-102.

${ }^{33}$ Alfrey AC. Dialysis encephalopathy syndrome. Annu Rev Med 1978;29:93-8.

${ }^{34}$ Platts MM, Goode GC, Hislop JS. Composition of the domestic water supply and the incidence of fractures and encephalopathy in patients on home dialysis. $\mathrm{Br} \mathrm{Med} \mathrm{J}$ 1977;ii:657-60.

${ }^{35}$ Dunea G, Mahurkar SD, Mamdani B, Smith EC. Role of aluminum in dialysis dementia. Ann Intern Med 1978; $88: 502-4$

${ }^{36}$ Rozas VV, Port FK, Rutt WM. Progressive dialysis encephalopathy from dialysate aluminum. Arch Intern Med 1978;138:1375-7.

37 Rozas VV, Port FK, Easterling RE. An outbreak of dialysis dementia due to aluminum in the dialysate. J Dial 1978; 2:459-70.

${ }^{38}$ Masramón J, Ricart MJ, Caralps A, et al. Dialysis encephalopathy. Lancet 1978; i:1370.

${ }^{39}$ Buge A, Poisson M, Masson S, et al. Encéphalopathie réversible des dialysés après arrêt de l'apport d'aluminium. 6 cas. Nouve Presse Med 1979;8:2729-33.

${ }^{40}$ Elliott HL, Dryburgh F, Fell GS, Sabet S, Macdougall AI. Aluminium toxicity during regular haemodialysis. $\mathrm{Br}$ Med J 1978; i:1101-3.

${ }^{11}$ Pierides AM, Edwards WG, Cullum UX, McCall JT, Ellis HA. Hemodialysis encephalopathy with osteomalacic fractures and muscle weakness. Kidney Int 1980; 18:115-24.

12 Leather HM, Lewin IG, Calder E, Braybrooke J, Cox RR. The effect of water deionisers on dialysis bone disease and encephalopathy in Plymouth. Nephron 1981; (in press).

43 Parkinson IS, Ward MK, Feest TG, Fawcett RWP, Kerr DNS. Fracturing dialysis osteodystrophy and dialysis encephalopathy: an epidemiological survey. Larcet 1979; i :406-9.

${ }^{44}$ Report from the Registration Committee of the European Dialysis and Transplant Association (1980) Dialysis dementia in Europe. Lancet 1980;ii:190-2.

${ }^{45}$ Platts MM, Anastassiades E. Dialysis encephalopathy: precipitating factors and improvement in prognosis. Clin Nephrol $1981 ; 15: 223-8$.

${ }^{46}$ Elliott HL, Macdougall AI. Aluminium studies in dialysis encephalopathy. Proc Eur Dial Transplant Assoc 1978; $15: 157-63$.

47 Ward MK, Feest TG, Ellis HA, et al. Osteomalacic dialysis osteodystrophy: evidence for a water-borne aetiological agent, probably aluminium. Lancet 1978 ; i:841-5.
${ }^{48}$ Adhemar JP, Laederich J, Jaudon MC, et al. Dialysis encephalopathy. Diagnostic and prognostic value of clinical and EEG signs, and aluminium levels in serum and cerebrospinal fluid. Proc Eur Dial Transplant Assoc 1980;17:234-9.

49 Williams ED, Elliott HL, Boddy K, et al. Whole body aluminium in chronic renal failure and dialysis encephalopathy. Clin Nephrol 1980;14:198-200.

${ }^{50}$ Parkinson IS, Beckett A, Ward MK, et al. Aluminium: removal from water supplies. Proc Eur Dial Transplant Assoc 1979;15:586-7.

${ }^{51}$ Elliott HL, Macdougall AI, Fell GS, Gardiner PHE, Williams ED. Dialysis encephalopathy evidence implicating aluminum. Dial Transplant 1980;9:1027-30.

52 Tsukamoto Y, Iwanami S, Marumo F. Disturbances of trace element concentrations in plasma of patients with chronic renal failure. Nephron 1980;26:174-9.

${ }^{53}$ Smith DB, Lewis JA, Burks JS, Alfrey AC. Dialysis encephalopathy in peritoneal dialysis. JAMA 1980;244: 365-6.

${ }^{54}$ Gacek EM, Babb AL, Uvelli DA, Fry DL, Scribner BH. Dialysis dementia: the role of dialysate $\mathrm{pH}$ in altering the dialyzability of aluminum. Trans Am Soc Artif Intern Organs 1979;25:409-15.

55 Branger B, Ramperez P, Marigliano N, Mion H, Shaldon $S$, Mion C. Aluminium transfer in bicarbonate dialysis using a sorbent regenerative system: an in vitro study. Proc Eur Dial Transplant Assoc 1980;17:213-8.

${ }^{56}$ Kaehny WD, Alfrey AC, Holman RE, Shorr WJ. Aluminum transfer during hemodialysis. Kidney Int 1977; 12:361-5.

${ }^{57}$ Allain P, Thébaud H-E, Dupouet L, et al. Étude des taux sanguins de quelques métaux ( $\mathrm{Al}, \mathrm{Mn}, \mathrm{Cd}, \mathrm{Pb}, \mathrm{Cu}, \mathrm{Zn}$ ) chez les hémodialysés chroniques avant et après dialyse. Nouve Presse Med 1978;7:92-6.

${ }^{58}$ Kovalchik MT, Kaehny WD, Hegg AP, Jackson JT, Alfrey AC. Aluminum kinetics during hemodialysis. $J$ Lab Clin Med 1978;92:712-20.

${ }^{59}$ Graf H, Stummvoll HK, Meisinger V. Desferrioxamineinduced changes of aluminium kinetics during haemodialysis. Proc Eur Dial Transplant Assoc 1981; (in press).

${ }^{60}$ Graf H, Stummvoll HK, Meisinger V, Kovarik J, Wolf A, Pingerra WF. Aluminum removal by hemodialysis. Kidney Int $1981 ; 19: 587-92$.

${ }^{61}$ Berlyne GM, Ben-Ari J, Pest D, et al. Hyperaluminaemia from aluminium resins in renal failure. Lancet 1970;ii: 494-6.

${ }^{62}$ Clarkson EM, Luck VA, Hynson WV, et al. The effect of aluminium hydroxide un calcium, phosphorus and aluminium balances, the serum parathyroid hormone concentration and the aluminium content of bone in patients with chronic renal failure. Clin Sci 1972;43:51931.

${ }^{63}$ Kaehny WD, Hegg AP, Alfrey AC. Gastrointestinal absorption of aluminum from aluminum-containing antacids. N Engl J Med 1977;296:1389-90.

${ }^{64}$ Boukari M, Rottembourg J, Jaudon MC, Clavel JP, Legrain M, Galli $A$. Influence de la prise prolongée de gels d'alumine sur les taux sériques d'aluminium chez les patients atteints d'insufficance rénale chronique. Nouve Presse Med 1978;7:85-8.

${ }^{65}$ Marsden SNE, Parkinson IS, Ward MK, Ellis HA, Kerr DNS. Evidence for aluminium accumulation in renal failure. Proc Eur Dial Transplant Assoc 1979;16:588-94.

${ }^{68}$ Zumkley $\mathrm{H}$, Bertram HP, Lison A, Knoll O, Losse $\mathrm{H}$. Aluminium, zinc and copper concentrations in plasma in chronic renal insufficiency. Clin Nephrol 1979;12:18-21.

${ }^{67}$ Kovarik J, Graf H, Meisinger V, Stummvoll HK, Wolf A. Influence of phosphate binders on serum aluminium levels in patients on chronic HD. Mineral and Electrolyte 
Metabolism 1979;2:242.

68 Jacobs C, Brunner FP, Chantler C, et al. Combined report on regular dialysis and transplantation in Europe V11, 1976. Proc Eur Dial Transplant Assoc 1977;14:3-67.

${ }^{69}$ Poisson M, Mashaly R, Lebkiri B. Dialysis encephalopathy: recovery after interruption of aluminium intake. Br Med J 1978;ii:1610-1.

io Pogglitsch von $\mathrm{H}$, Wawschinek O, Holzer $\mathrm{H}$, Petek W, Katschnig H, Ladurner G. Beziehungen zwischen Plasmaaluminium, peroraler Aluminium hydroxydaufnahme und Enzephalopathiesymptomen bei Dauerdialysepatienten. Nieren- und Hochdruckkrankheiten 1980;5:3-8.

7 Mehta RP. Encephalopathy in chronic renal failure appearing before the start of dialysis. CMA Journal 1979; $120: 1112-4$.

72 Geary DF, Fennell RS, Andriola M, Gudat J, Rodgers BM, Richard GA. Encephalopathy in children with chronic renal failure. J Pediatr 1980;97:41-4.

${ }^{73}$ Masselot JP, Adhemar JP, Jaudon MC, Kleinknecht D, Galli A. Reversible dialysis encephalopathy: role for aluminium-containing gels. Lancet 1978; ii:1386-7.

${ }^{74}$ Rutherford E, King S, Perry B, et al. Use of a new phosphate binder in chronic renal insufficiency. Kidney Int 1980;17:528-34.

is Ackrill P, Ralston AJ, Day JP, Hodge KC. Successful removal of aluminium from patient with dialysis encephalopathy. Lancet 1980;ii:692-3.

${ }^{76}$ Kerr DNS. Renal osteomalacia. In: Zurukzoglu W, Papadimitriou M, Pyrpasopoulos M, Sion M, Zamboulis
C, eds. Proceedings of the Eighth International Congress of Nephrology. Basle: Karger, $1981: 221-8$.

7 Druëke T. Dialysis osteomalacia and aluminum intoxication. Nephron 1980;26:207-10.

is Cochran M, Platts MM, Moorhead PJ, Buxton A. Spontaneous hypercalcaemia in maintenance dialysis patients: an association with atypical osteomalacia and fractures. Mineral and Elestrolyte Metabolism 1981;5: 280-6.

is Ellis HA, McCarthy $\mathrm{JH}$, Herrington $\mathrm{J}$. Bone aluminium in haemodialysed patients and in rats injected with aluminium chloride: relationship to impaired bone mineralisation. J Clin Pathol 1979;32:832-44.

${ }^{89}$ Cournot-Witmer G, Zingraff J, Plachot J-J, et al. Aluminum localization in bone from hemodialyzed patients: relationship to matrix mineralization. Kidney Int 1981; (in press).

${ }^{81}$ Hodsman AB, Sherrard DJ, Wong EGC, et al. Vitamin-Dresistant osteomalacia in hemodialysis patients lacking secondary hyperparathyroidism. Ann Intern Med 1981; 94:629-37.

${ }^{2}$ Short AIK, Winney RJ, Robson JS. Reversible microcytic hypochromic anaemia in dialysis patients due to aluminium intoxication. Proc Eur Dial Transplant Assoc 1980;17:226-33.

Requests for reprints to: Professor DNS Kerr, Department of Medicine, Royal Victoria Infirmary, Newcastle upon Tyne NE1 4LP, England. 